\title{
OBITUARY
}

\section{ANTHONY GREEN, BA, PhD}

$$
\text { (1956-2012) }
$$

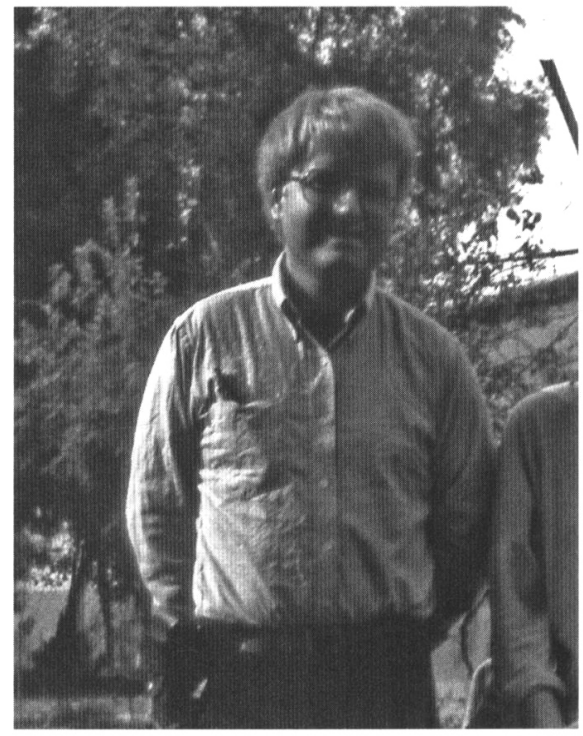

Friends and colleagues in many parts of the world, but particularly in Britain and Germany, were greatly saddened by the death of Dr Anthony Raymond Green on 19th June 2012, at the early age of fifty-six years. Although Tony had been in poor health for some time, his premature passing still came as a great shock to all in the field. He was born on 25th April 1956 and grew up in Aldershot in Hampshire. He studied with Charles Burney at the University of Manchester, where he obtained a BA in Ancient History and Archaeology, specializing in the Near East in the period of the Assyrian Empire. He went on to do a $\mathrm{PhD}$ thesis on Neo-Assyrian Apotropaic Figures: with special reference to the Human Heroes and Human-Animal Hybrids: Iconography, Chronology, Identification and Significance. This was submitted in a magisterial four volumes in 1983. Apotropaic figures were to remain an abiding interest for the whole of Tony's life, and he made important contributions in this field. Foremost amongst them is a 100-page article in Baghdader Mitteulingen (vol. 17 for 1986) on the lion-demon, but there were also articles in Iraq, Altorientalische Forschungen, the Reallexikon der Assyriologie and elsewhere. His expertise in religious iconography stood him in good stead when collaborating with Jeremy Black (d. 2004, obituary Iraq 66, 2004) and Tessa Rickards on their Gods, Demons and Symbols of Ancient Mesopotamia: an Illustrated Dictionary. This book was published by the British Museum in 1992, and has proved to be very successful. It was reprinted in 1998, and there have been translations into Polish and Czech. He also worked for many years on a volume on the terracotta figurines found during the BISI excavations at Nimrud between 1949 and 1963. This project had not been completed at the time of his death, but it is believed that it is sufficiently well advanced for early publication to be possible.

Before he was overtaken by ill-health, Tony was also active in the field. His introduction to Near Eastern archaeology came in 1978 when he joined the last season of excavation at Haftavan Tepe in North-West Iran, directed by Charles Burney, although for much of that season Charles was involved with the Meshkinshahr survey. Then, between 1978 and 1981 he worked with Nicholas Postgate at Tell Abu Salabikh in Southern Iraq, for part of the time overseeing the excavation of a Sumerian ash-tip containing sealings, figurines and other small objects. In due course he edited the final report on this feature that was published as Abu Salabikh Excavations vol. 4 in 1993. In 1985-6 he joined the British Museum expedition working in the southern part of the Eski Mosul Dam Salvage Project, directed by myself, working at the Late Assyrian site of Khirbet Khatuniyeh, the Hellenistic sites of Tell Deir Situn and Grai Darki, and the Sasanian-Islamic period church at Khirbet Deir Situn. Khirbet Khatuniyeh in particular proved to be a site with extraordinary potential, but excavations 
were cut short by the rising waters behind the dam. Tony co-authored the final report that was published by the British Museum in 1997 (Excavations at Khirbet Khatuniyeh, by John Curtis and Anthony Green). In the early part of 1986 he also supervised the excavations of the British Archaeological Expedition to Iraq at Khirbet Shireena in the northern part of the Eski Mosul Dam Salvage Project. This site was interpreted as a small Late Assyrian farmstead dependent on the larger settlement at Tell Abu Dhahir, and an account was published by Tony in Warwick Ball, ed., Ancient Settlement in the Zammar Region, vol. 1 (Oxford 2003). In 1989 he again joined up with the British Museum team for a season at Nimrud and Balawat which it was hoped would be the start of a longlasting project, but this hope was frustrated by the onset of the first Gulf War in 1991. Nevertheless, the results of the first season were very promising, particularly at Nimrud, and Tony collaborated in the final report that was published in $\operatorname{Iraq}$ (vol. 55 for 1993).

After a lapse of some years, in 1997 he joined the German excavations at Tell Sheikh Hamad in Syria, directed by Hartmut Kühne, and in 1998-9 he collaborated with Arnulf Hausleiter in undertaking a surface survey of the lower town at Tell Ahmar (Til Barsip) in Syria. Tony's long-standing interest in Assyrian excavation and material culture was reflected in an article about the Eski Mosul region in the Neo-Assyrian and Post-Assyrian periods that he wrote for a volume on Iron Age pottery edited by Arnulf Hausleiter and Andrzej Reiche (Münster 1999), and a contribution to the 2002 Nimrud Conference (published by BISI in 2008) on the activities of the Swiss businessman Julius Weber at Nimrud.

Like many Near Eastern archaeologists of his generation Tony did not have the good fortune to secure the regular employment that he richly deserved, and in the 1980s and 1990s he was dependent on a series of grants and fellowships from various bodies including the British School of Archaeology in Iraq, the Gerald Avery Wainwright Fund of Oxford University, and the J. Paul Getty Postdoctoral Programme at the University of Pennsylvania. During this time, he was based mainly in Oxford. A particularly successful initiative of these years was a conference on 'The Archaeology of Death in the Ancient Near East' that was jointly organized with Stuart Campbell at the University of Manchester in 1992. The edited papers, 30 in all, were published in 1995. Then in 1996 he was awarded a prestigious Alexander von Humboldt Fellowship in Near Eastern Archaeology at the Free University in Berlin. This gave him the use of a room in the Free University, which he was able to keep until a few years before his death. Meanwhile, in 1994 he had married Estrella Cuesta from Cebu City in the Philippines, and their daughter Kasha was born in Berlin in 1997. From then onwards, they made their home in Berlin.

From 1999 until his death, Tony was generously supported by the Shumei Foundation to work, based in Berlin, on the collections of the Miho Museum, the museum designed by I.M. Pei in the mountains near Kyoto in Japan. The main focus of this work was the large collection of goldwork acquired by the museum, thought to be a temple hoard of the Achaemenid or Hellenistic period from somewhere in Central Asia. Because of a superficial resemblance to the Oxus Treasure in the British Museum, it is sometimes misleadingly referred to as 'the Second Oxus Treasure', but is now more generally known as 'the Bactrian Treasure'. In all, four volumes were planned: a volume of essays by various scholars in memory of Igor Pichikiyan; a new and complete catalogue of the 'Treasure of Bactria', based on the work of Igor Pichikiyan; a catalogue of the pre-Achaemenid silver vessels in the Miho Museum, with $\mathrm{H}$, Inagaki; and a republication of studies on the Soviet excavations at Takht-i Sangin in Tajikistan. The Miho Museum is also intending to publish the results of the more recent work at Takht-i Sangin, between 1998 and 2010. The status of these publications is at present uncertain, but it is hoped that some of this work will in due course see the light of day.

Tony was able to make a lengthy visit to Japan in 2000 to study material in the Miho Museum at first hand, but thereafter he was beset by medical problems that rendered travel very difficult. Later that year he was obliged to start dialysis, and this, combined with many complications, clouded the last twelve years of his life. Nevertheless, he endured his long illness with great fortitude, attempting to work right up until the end, and he never lost his wonderful sense of humour. He was buried in the beautiful Steglitz Cemetery in South Berlin on 6th July 2012. He is survived by Estrella, their daughter Kasha, and two daughters from Estrella's first marriage. Tony will be remembered as a popular colleague and a determined and indomitable character who in the face of great adversity made his mark in Near Eastern archaeology.

John E. Curtis 